\title{
Students' Perspectives Toward News Voiceover Activity in Pronunciation Class
}

\author{
Suprayogi, Budi Eko Pranoto \\ Universitas Teknokrat Indonesia \\ Bandar Lampung, Indonesia \\ suprayogi@teknokrat.ac.id, budiekopranoto@gmail.com
}

\begin{abstract}
This study aims at revealing students' perspective toward the implementation of news voiceover activity in pronunciation class. This study employed qualitative descriptive method by selecting 40 tertiary students enrolling Pronunciation Course in English Education study program in a tertiary level in Indonesia. Data were collected through questionnaire and interviews. The data were analyzed qualitatively. The findings show that news voiceover activity was perceived positively by the students. It was found that news voiceover activity helped them to improve the quality of pronunciation, to be more aware of steps to create good pronunciation and to have model of learning pronunciation independently. This study suggests that the activity in improving students' pronunciation through the integration of technology in the teaching process is indeed significant.
\end{abstract}

Keywords: EFL learner, pronunciation, students' perspective, voiceover

\section{INTRODUCTION}

In the era of industrial revolution 4.0, the advanced-mastery of English is indeed important for global communication. Heller (1999 in Block \& Cameroon, 2002) stated that foreign language is seen as economic commodity, so is English. This also shows that English becomes potential opportunity to be developed as an asset both for the learners and for the English language teachers themselves. Moreover, for the specific context, as the future teachers and language practitioners, students of English Education will be the role model for many English activities, more importantly, in pronunciation modeling.

Pronunciation is an inseparable part of speaking and it is inevitably important to understand the meaning exchanged in the communication process. Good pronunciation skills help these students to delivering materials as well as understanding discourses in many contexts of communication. In English Education study program, the practice of pronunciation is introduced in the students' first year. This is expected that students master the concept of sound production in English that can make them easier to follow the courses of speaking and listening in the following semesters. The condition, in fact, is that most of the students are still struggling to pronounce basic vocabulary and applying English phonology in their daily communication. This may be because the feature of English phonology is far different from Indonesian phonology.
To cope with this problem, a learning model that integrates technology is needed. Maszkowska (2017) stated that modern technology for learning enable students develop their skills needed for the future workforce. Furthermore, technology is essential to develop learners' creativity and offers attractive and enjoyable, and exciting choice for language study (Ahmadi, 2018). In line with this, pronunciation learning using technology is proposed to be an alternative.

For the past five years, researches on teaching pronunciation through technology have been conducted. Stanculea (2015) implemented teaching pronunciation through song, meanwhile Tewari and Goyal (2014) observed the quality of pronunciation after the activity of gaming; however, the research on voice over activity to support pronunciation practice has not been widely conducted. News voice over is basically an activity of integrating segmental features and suprasegmental features of language, where students does not only consider how to pronounce each word but also take intonation, tempo and stress into account to produce quality voice.

This study aims at uncovering students' perspectives toward the implementation of news voiceover activity in Pronunciation class of English Education study program. Knowing the students' perspectives is paramount as they are the object of activity who directly feel the process and impact. Furthermore, data related to students' perspective becomes the fundamental information to develop a pronunciation learning model.

\section{METHOD}

This study was conducted in a private tertiary education in Lampung province, Indonesia. The subjects of this study were 40 students in English Education study program in academic year of 2018/2019. These students are first semester student which enrolled Pronunciation course i.e. the class of PI A 2018. Pronunciation course is a course in this study program designed to introduce students in the first semester the basic pronunciation in English. This class weighs 2-credit semester for 16 meeting.

Highlighting that successful projects require considerable in-class as well as out-of-class preparation (Burston, 2005), thus the activity of creating news voice over was conducted in meeting 14 and 15 which is take-home assignments. 
Meanwhile, the project submission and evaluation is conducted in meeting 16 in which the news voice over project becomes their final exam. News voice over project in this context is a project of rereading the news script aloud using audio recording, where the recording file is inserted in the original video. Students were asked to choose a 3-5 minute video from NHK World YouTube channel and to make create voice over from the video.

Data of students' perspective in this research were obtained through questionnaire and interview. The questionnaire of consisting of 15 statements were distributed to the students. The statements contain the idea usefulness, practicality, and impact of news voice over activity which should be responded by the students using Likert scale of strongly agree, agree, disagree, and strongly disagree. The questionnaire was distributed in the meeting 16.The responses were then analyzed to see whether students have good perspective or not toward the activity of news voice over. The interpretation was adopted from Riduwan (2008) where it is interpreted very significant if it reaches $81-100 \%$, significant in $61-80 \%$, insignificant in $41-$ $60 \%$, and very insignificant in $0-20 \%$.

\section{FINDINGS AND DISCUSSION}

The discussion covers students' perspective towards the activity of news voice over in terms of their motivation, pronunciation concern, improvement, effectiveness and fun. Based on the questionnaire consisting of 15 statements distributed the respondent, there were various responses toward the given statements. The following table reflects first point of discussion on how activity of voice over improves their concern toward pronunciation seen in the following statements.

TABLE I. StUdents' PERSPECTIVES (PRONUNCIATION AWARENESS

\begin{tabular}{|c|c|c|c|}
\hline 4 & 3 & 2 & 1 \\
\hline \multicolumn{4}{|c|}{$\begin{array}{l}\text { News voice over project maintains my understanding on } \\
\text { expected pronunciation performance. }\end{array}$} \\
\hline $\begin{array}{c}22 \\
(55 \%) \\
\end{array}$ & $\begin{array}{r}(18) \\
45 \% \\
\end{array}$ & $\begin{array}{c}0 \\
(0 \%) \\
\end{array}$ & $\begin{array}{l}0 \\
(0 \%) \\
\end{array}$ \\
\hline \multicolumn{4}{|c|}{$\begin{array}{l}\text { News voice over project enables me to pay attention to the } \\
\text { detail aspect of pronunciation performance. }\end{array}$} \\
\hline $\begin{array}{c}21 \\
(52.5 \%)\end{array}$ & $(47.5 \%)$ & $\begin{array}{c}0 \\
(0 \%)\end{array}$ & $\begin{array}{c}0 \\
(0 \%)\end{array}$ \\
\hline \multicolumn{4}{|c|}{ I am more sensitive to mispronounced words. } \\
\hline $\begin{array}{c}21 \\
(52.5 \%)\end{array}$ & $\begin{array}{c}19 \\
(47.5 \%)\end{array}$ & $(0 \%)$ & $\begin{array}{c}0 \\
(0 \%)\end{array}$ \\
\hline \multicolumn{4}{|c|}{$\begin{array}{c}\text { Now I know that in news voice over, I should take intonation } \\
\text { into account. }\end{array}$} \\
\hline $\begin{array}{c}24 \\
(60 \%)\end{array}$ & $\begin{array}{c}15 \\
(37.5 \%)\end{array}$ & $\begin{array}{c}1 \\
(2.5 \%)\end{array}$ & $\begin{array}{c}0 \\
(0 \%)\end{array}$ \\
\hline \multicolumn{4}{|c|}{$\begin{array}{l}\text { Through news voice over project, I think that pronunciation is } \\
\text { very fundamental for language learning. }\end{array}$} \\
\hline $\begin{array}{c}20 \\
(50 \%)\end{array}$ & $\begin{array}{c}19 \\
(47.5 \%)\end{array}$ & $(2.5 \%)$ & $\begin{array}{l}0 \\
(0 \%)\end{array}$ \\
\hline
\end{tabular}

There are 22 students (55\%) who strongly agree and 18 students $(45 \%)$ who agree that news voiceover project maintains their understanding on expected pronunciation performance. This activity makes them aware that when their pronunciation should be correct and clear because their voice plays an important role to describe visual part in the video. This is supported by the following extract.

\section{"I become more aware of my pronunciation" (DMS) \\ "It gives me editing experiences and I can be more aware of my pronunciation" (CAP)}

In the next statement, All students (52.5\% and 47.5\%) think that the activity makes them aware on the detail aspect of pronunciation, which is the suprasegmental features learned in the class i.e. stress, intonation, pitch, strong form and weak form. This is supported by the next statement that they very significantly take intonation into account $(60 \%)$ when they do the project of news voice over; however, 1 student disagrees about this statement. Mostly, they are aware that as the one who does voiceover, appropriate intonation can support the video content quality, as seen in the following extract.

"I can improve my pronunciation and I can be more aware of
strong form \& weak form of word" (SMS)
"I can read English sentences fast and I know the way how to
speak with good intonation" (TS)
"This project helps me to have a good intonation as a presenter and by listening, I realize that pronunciation is a crucial thing', (KNP)

From the extract, it can be seen that the voice over project provide modeling of authentic English used daily professional communication; therefore, they learn from it. Furthermore, students are very significantly more sensitive to mispronounced words ( $52.5 \%$ or 21 student). This makes them aware that mispronounced word will lead to meaning ambiguity and misunderstanding. Although 1 student disagree that pronunciation is fundamental in language learning, Most of them strongly agree $(50 \%)$ that pronunciation is indeed. This is supported by the following extract.

"I know my strength and weaknesses so I can evaluate myself to have good pronunciation" (A)

"This project makes me realize of my mistakes in pronouncing words" (AA)

In general, on how voiceover makes them aware of the importance of pronunciation and its aspects, the questionnaire shows very significant result.

The second discussion is on how the activity of voice over project has the correlation with motivation. In terms of improvement, students' perspective can be seen in the following table.

TABLE II. STUDENTS' PERSPECTIVES (IMPROVEMENT)

\begin{tabular}{|c|c|c|c|}
\hline $\mathbf{4}$ & $\mathbf{3}$ & $\mathbf{2}$ & $\mathbf{1}$ \\
\hline \multicolumn{4}{|c|}{ News voice over project improves my confidence in reading } \\
sentences. \\
\hline 17 & 23 & 0 & 0 \\
$(42.5 \%)$ & $(57.5 \%)$ & $(0 \%)$ & $(0 \%)$ \\
\hline I think my skill of pronunciation has improved since I do news \\
\multicolumn{4}{|c|}{ voice over project. } \\
\hline 13 & 20 & 6 & 1 \\
$(32.5 \%)$ & $(50 \%)$ & $(15 \%)$ & $(2.5 \%)$ \\
\hline
\end{tabular}


There are 17 students (42.5\%) who strongly agree that this project improve their confidence in reading sentence, and 23 students $(57.5 \%)$ agree about the statement and no one disagree. Thus based on their perspective, this activity significantly improves their confidence in reading sentence. Furthermore, 20 students (50\%) admitted that since they do this project, their pronunciation has been improved, and 13 strongly agree about it. However, there were 7 students who think that their pronunciation quality has not been improved yet.

\section{"This projects improve my confidence and helps me to have good reading" $(\mathrm{FH})$. \\ "This project is so fun and gives me new experience. My pronunciation becomes better than before." (MDW).}

From those extracts, it was implied that they do reflective evaluation and they think that some areas have been improved. Besides this improvement, this research also concerns on the effectiveness of the voice over project. The following table reflects the result of students' perspective related to the effectiveness.

TABLE III. STUdents' PeRsPectives (EFFECTIVENESS)

\begin{tabular}{|c|c|c|c|}
\hline 4 & $\mathbf{3}$ & 2 & 1 \\
\hline \multicolumn{4}{|c|}{$\begin{array}{l}\text { I think it is not effective to do video dubbing project to the } \\
\text { result of my learning. }\end{array}$} \\
\hline $\begin{array}{c}1 \\
(2.5 \%)\end{array}$ & $\begin{array}{c}5 \\
(12.5 \%)\end{array}$ & $\begin{array}{c}25 \\
(62.5 \%)\end{array}$ & $\begin{array}{c}9 \\
(22.5 \%)\end{array}$ \\
\hline \multicolumn{4}{|c|}{ If in the future, I have voice over activity, I can do it myself. } \\
\hline $\begin{array}{c}9 \\
(22.5 \%)\end{array}$ & $\begin{array}{c}28 \\
(70 \%)\end{array}$ & $\begin{array}{c}3 \\
(7.5 \%)\end{array}$ & $\begin{array}{c}0 \\
(0 \%)\end{array}$ \\
\hline \multicolumn{4}{|c|}{$\begin{array}{c}\text { News voice over encourages me to continue learning } \\
\text { pronunciation. }\end{array}$} \\
\hline $\begin{array}{c}17 \\
(42.5 \%)\end{array}$ & $\begin{array}{c}20 \\
(50 \%)\end{array}$ & $\begin{array}{c}3 \\
(7.5 \%)\end{array}$ & $\begin{array}{c}0 \\
(0 \%)\end{array}$ \\
\hline \multicolumn{4}{|c|}{$\begin{array}{l}\text { It is worth to prepare and make the video with the result that I } \\
\text { have. }\end{array}$} \\
\hline $\begin{array}{c}8 \\
(20 \%)\end{array}$ & $\begin{array}{c}26 \\
(65 \%)\end{array}$ & $\begin{array}{c}6 \\
(15 \%)\end{array}$ & $\begin{array}{c}0 \\
(0 \%)\end{array}$ \\
\hline
\end{tabular}

In terms of its effectiveness, voice over project is perceived variously. It is shown that $6(15 \%)$ don't see this project effective meanwhile 34 students $(85 \%)$ admitted that this activity is effective to the result of their learning process. In addition, 37 students $(92.5 \%)$ feel that this activity is replicable for them in meaning that they can do it independently in the future whenever they are asked or want to do the same activity. Nevertheless, 3 students still cannot do it by themselves. From the table, it can also be seen that the students are very significantly encouraged $(42.5 \%)$ to continue learning pronunciation after doing this activity; however, 3 of them not. They further agree $(65 \%)$ that the activity is worth to do.

"I really love this activity because it is exciting and I like practical learning" $(\mathrm{NN})$

"Dubbing video is interesting to be teaching method to improve my pronunciation. I can pronounce words more expressive" (SG)
TABLE IV. STUdENTS' PeRSPeCtive (EXCITEMENT TOWARD THE ACTIVITY)

\begin{tabular}{|c|c|c|c|}
\hline $\mathbf{4}$ & $\mathbf{3}$ & $\mathbf{2}$ & $\mathbf{1}$ \\
\hline \multicolumn{4}{|c|}{ I enjoy doing voice over project activity. } \\
\hline 14 & 25 & 1 & 0 \\
$(35 \%)$ & $(62.5 \%)$ & $(2.5 \%)$ & $(0 \%)$ \\
\hline \multicolumn{4}{|c|}{ I feel bored voice over project activity. } \\
\hline 0 & 4 & 25 & 11 \\
$(0 \%)$ & $(10 \%)$ & $(62.5 \%)$ & $(27.5 \%)$ \\
\hline
\end{tabular}

On the point of joy, 36 students (90\%) enjoy voice over project activity and 4 of them not. This shows that this activity is significant for them. Their excitement lies on how they know the practical field where the pronunciation becomes important aspect. This is supported by the following extract.

\section{"I can learn how to be a good reporter" (ETA) \\ "I love making dubbing video because I feel like a real presenter" (FA) \\ "This is interesting project because I learn something new in dubbing and It supports my dream to be a dubber" (NIN)}

This activity is considered new for them and they can find alternative to learn. In addition, in relation to their profession in the future, they also have positive responses, as seen in the following table.

TABLE V. Students' Perspective (Future ENGLish Teacher)

\begin{tabular}{|c|c|c|c|}
\hline $\mathbf{4}$ & $\mathbf{3}$ & $\mathbf{2}$ & $\mathbf{1}$ \\
\hline \multicolumn{4}{|c|}{ Voice over project makes me inspired to do such program for } \\
my future student. \\
\hline $\begin{array}{c}18 \\
45 \%\end{array}$ & $\begin{array}{c}22 \\
55 \%\end{array}$ & $0 \%$ & $0 \%$ \\
\hline \multicolumn{4}{|c|}{ learning is important. } \\
\hline I think as a future teacher, integrating technology and language \\
\hline \multicolumn{4}{|c|}{$\begin{array}{c}0 \\
(65 \%)\end{array}$} \\
\hline
\end{tabular}

There are students (45\%) who strongly agree that this activity can be the inspiration for task-based or project-based learning for their future students when they become the teacher later. They further believed that integrating technology in language learning $(65 \%)$ is indeed essential.

From five aspects that are analyzed, it can be seen that in general students perceived the voice over activity positively. The result of each item is mostly very significant. They become more aware of pronunciation aspect because they are trained to have series of step to do. They also think that they activity fits to their characteristic of gen $Z$, they are not afraid of being introduced with new technology. This study further supported by Kurnia and Mursyid (2017) that voice over or dubbing activity is easy to follow and fun.

\section{CONCLUSION}

News voice over activity has shown its practical implementation in terms of pronunciation awareness, effectiveness, pronunciation improvement, fun aspect, relation 
to teacher as students' future job. This practicality is at least seen from the students in as the ones who are involved in this activity directly. Therefore, this activity is highly suggested to be implemented in pronunciation class. This activity, further, integrate mobile phone, video editor, laptop and YouTube to be their tools to learn as well as experience to make a product of learning. It is, then, in line learning foreign language in the ear of industry 4.0 where practical learning is highly promoted and utilization of internet and mobile technology can be maximized.

\section{REFERENCES}

Ahmadi, R. M. (2018). The use of technology in English language learning: A literature review, International Journal of Research in English Education, 3(2), 115-125.
Block, D. \& Cameron, D. (2002). Globalization and Language Teaching. London and New York: Routledge. p.5.

Burston, J. (2005). Video dubbing projects in the foreign language curriculum, CALICO Journal, 23, 79-92. doi: 10.1558/cj.v23i1.79-92

Kurnia, A. \& Mursid (2017). The technique of dubbing in teaching pronunciation, Proceeding International Seminar on Language Education (ISLE), 40-51.

Maszkowska, N. (2017). The use of technology in English. Retrieved from http://gizemgencturkelt.blogspot.com/search/label/http\%3A\%2F\%2F englishcontext.kpnu.edu.ua\%2F2017\%2F04\%2F18\%2Fthe-use-oftechnology-in-english-language-teaching $\% 2 \mathrm{~F}$

Riduwan (2008). Belajar Mudah Penelitian untuk Guru-Karyawan dan Peneliti Pemula. Bandung: Alfabeta.

Stanculea, A. N. (2015). Teaching Pronunciation through Songs. Journal Plus Education, 12(2), 177-184.

Tewari, A. \& Goyal. N (2014). Speech and Pronunciation Improvement through Games for Hispanic Children. Retrieved from https://arxiv.org/ftp/arxiv/papers/1401/1401.7735.pdf August 26 2019. 